\title{
Movilidad Intergeneracional e Igualdad de Oportunidades: el caso del NOA
}

Intergenerational Mobility and Equality of Opportunities in North-West Argentina

Mobilidade Intergeracional e Igualdade de Oportunidades: o caso do NOA.

\author{
Andrés Ramasco \\ Universidad Nacional de Tucumán, Argentina \\ E-mail: ramascoandres@gmail.com
}

Fecha de recepción: 29/10/2019

Fecha de aceptación: 28/11/2019

Palabras clave

\section{Resumen}

Esta investigación propone analizar empíricamente el fenómeno de la movilidad intergeneracional de la educación, llevando a cabo una caracterización a nivel regional y poniendo énfasis en el NOA. La estrategia utilizada en el trabajo son estadísticas descriptivas y un modelo probit para el caso de la movilidad absoluta (comparación con progenitores) y regresiones para el caso de la movilidad relativa (cambios en la distribución a través del tiempo), disgregando por género y para inmigrantes limítrofes. En este estudio estimamos los coeficientes de persistencia intergeneracional de la educación, y un modelo probit para buscar los determinantes de que un individuo salga 0 no de la pobreza 0 persista 0 no en la riqueza luego de una generación. Obtenemos como resultado que los hijos heredan alrededor de medio año de educación adicional por cada año de educación adicional de sus padres, y que existen ciertas diferencias entre regiones. Otro resultado importante es la informalidad del empleo del jefe de hogar como variable explicativa de la persistencia de la pobreza. Por otro lado, otro hallazgo importante es la informalidad del empleo del jefe de hogar como variable explicativa de la persistencia de la pobreza, como contraparte de esto, individuos cuyos padres poseen un empleo de cuello blanco poseen mayor probabilidad de persistir en la parte superior de la distribución de educación. 
Keywords

- IM

- Mobility

- Equality of Opportunities

- Education

Palavras-chave

- MI

- Mobilidade

- Igualdade de Oportunidades

- Educação

\section{Abstract}

The aim of this research is to do an empirical analysis of the phenomenon of intergenerational mobility in education, typifying by region, with special attention to the North-West region of Argentina. The strategy consists of descriptive statistics and a probit model in the case of absolute mobility (a contrast between children and their parents), and a regression analysis in the case of relative mobility (changes in the distribution throughout time), making a separation based on gender and origin (people from neighboring countries). In this study, the rate of intergenerational educational persistence is calculated, and a probit model is used to find the factors that determine whether an individual moves out of poverty or not and whether an individual stays wealthy or not after one generation. As a result, we find that children inherit about half a year of additional education for each year of additional education attained by their parents; these findings differ from one region to another. In addition, an important finding reveals that the informal job of the head of family is a variable that explains poverty persistence; in contraposition, the children of white collar workers are more likely to stay in the top of the distribution of education.

\section{Resumo}

Esta pesquisa propõe analisar empíricamente 0 fenômeno da mobilidade intergeracional da educação, fazendo uma caracterização a nível regional e pondo ênfase no NOA. A estratégia utilizada no trabalho são estatísticas descritivas e um modelo Probit para 0 caso da mobilidade absoluta (comparação com progenitores) e regressões para 0 caso da mobilidade relativa (mudanças na distribuição através do tempo), desagregando por gênero e para imigrantes limítrofes. Neste estudo estimamos os coeficientes de persistência intergeracional da educação, e um modelo Probit para procurar os determinantes de que um indivíduo saia ou não da pobreza ou persista ou não na riqueza depois de uma geração. Obtemos como resultado que os filhos herdam ao redor de meio ano de educação adicional por cada ano de educação adicional de seus pais, e que existem certas diferenças entre regiões. Por outro lado, outra descoberta importante é a informalidade do emprego do chefe de família como variável explicativa da persistência da pobreza, como contraparte disto, indivíduos cujos pais possuem um emprego de colarinho branco possuem maior probabilidade de persistir na parte superior da distribuição de educação. 